\title{
Obesity's role in MS
}

\section{An intervention target with possible interactions}

Kathryn C. Fitzgerald, SCD, and Ellen M. Mowry, MD, MCR

Neurol Neuroimmunol Neuroinflamm 2021;8:e932. doi:10.1212/NXI.0000000000000932

In the accompanying study by Hedström et al., the investigators explore modifying effects of several well-known MS risk factors. They consider excess risk and synergistic effects of obesity, Epstein-Barr virus (EBV) infection, and genetic factors (human leukocyte antigen [HLA]DRB1*15:01, primarily) on the risk of MS in 2 Swedish population-based cohorts. Findings describe that overweight and obesity in young adulthood confer a nonadditive effect on the risk of MS among those with a history of EBV infection or are HLA-DRB1*15:01 carriers.

Assuming a lack of bias, deviation from risk additivity suggests that some subgroups would theoretically benefit more (e.g., obtain a greater absolute risk reduction) from a specific intervention than other individuals would. ${ }^{1}$ In this case, the observed departure from additivity associated with obesity among EBV-infected or HLA-DRB1*15:01 carriers implies that reduction in body weight would be most beneficial for those with a previous history of EBV infection or carry HLA-DRB1*15:01 alleles. Further excess risk above additivity for multiple exposures (e.g., superadditivity, or the 3-way interactions tested here) may be particularly valuable from a preventive medicine perspective because risk for the outcome could be theoretically be reduced considerably by intervening on either exposure, assuming both are causal and modifiable. ${ }^{1,2}$

As with most epidemiologic research, some assumptions and data requirements are necessary to obtain valid inference. Those related to interaction rely intricately on adequate control of confounding and, often, rely on large effects of the study exposures in question to make reliable conclusions pertaining to biologic interaction. ${ }^{1,2}$ Relatedly, a large sample size is also necessary, particularly in the context of assessment of risk superadditivity ${ }^{1}$ (3-way interactions) included in this report. Herein, these conditions were relatively true. Some of study design elements, however, may potentially have introduced bias. The median disease duration at enrollment was 2 and 18 years for the 2 included cohorts, which may affect the interpretability of the EBV nuclear antigen-1 titers. Relatedly, the assessment of body mass index at age 20 years, infectious mononucleosis history, and some of the other confounders was retrospective and self-reported. Last, 1 additional concern is the differential response rates in cases and control populations potentially inducing some selection bias; the prevalence of obesity or the distribution of body weight (or other potential confounders) may differ among those who respond to the survey vs those who do not, especially in the non-MS controls.

The reproducibility of the observed interaction effects (especially for observed 3-way interactions) in other populations would be a valuable next step; some studies in non-Northern European populations do not observe excess risk of MS for HLA-DRB1*15:01 carriers associated with EBV infection. ${ }^{3,4}$ Furthermore, exploration of the dose-response for early adulthood body mass index, incorporating more flexible modeling strategies (rather than the dichotomous overweight vs nonoverweight), would additionally bolster the findings.

Identification of underlying mechanisms of interaction depends on biologic assumptions that are often difficult to verify using epidemiologic data alone, even in the context of large effect sizes, optimal data, and control for confounding. For this study, detailed information describing the biological mechanisms that might explain the findings is not well known. Some hypothesized

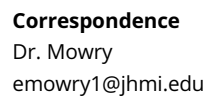

\section{RELATED ARTICLE}

Overweight/obesity in young adulthood interacts with aspects of EBV infection in MS etiology

Page e912 
mechanisms include that an already primed proinflammatory immune system in people with high genetic risk for MS (e.g., HLA-DRB1*15:01 carriers), or among those with previous EBV infection, is exaggerated by the low-grade inflammatory state observed in obese individuals, which then confers an excess risk for MS. ${ }^{5-8}$ It is important to note that the genetic burden of MS risk and EBV infection (outside the context of an effective vaccine that is currently not available) is largely nonmodifiable, ${ }^{9}$ whereas body weight is at least somewhat modifiable. Thus, from a public health perspective, the results of this study continue to highlight that obesity prevention and maintenance of a healthy weight, especially earlier in life, remains a critical component in MS prevention in both subgroups of individuals with a higher MS risk (e.g., those with a family history of MS) as well as overall (because early-life obesity itself is a risk factor for MS).

\section{Author contributions}

K.C. Fitzgerald: drafting/revision of the manuscript for content, including medical writing for content. E.M. Mowry: drafting/revision of the manuscript for content, including medical writing for content.

\section{Study funding}

No targeted funding reported.

\section{Disclosure}

K.C. Fitzgerald has no disclosures. E.M. Mowry's institution has received research support from Biogen (for investigatorinitiated study and for studies for which she is site PI) and Genzyme (for investigator-initiated study) and free medication for a clinical trial (of which she is PI) from Teva. She has received royalties for editorial duties from UpToDate. Go to Neurology.org/NN for full disclosures.

\section{References}

1. Greenland S. Interactions in epidemiology: relevance, identification, and estimation. Epidemiology 2009;20:14-17.

2. Siemiatycki J, Thomas DC. Biological models and statistical interactions: an example from multistage carcinogenesis. Int J Epidemiol 1981;10:383-387.

3. Simon KC, van der Mei IaF, Munger KL, et al. Combined effects of smoking, antiEBNA antibodies, and HLA-DRB1*1501 on multiple sclerosis risk. Neurology 2010 ; 74:1365-1371.

4. De Jager PL, Simon KC, Munger KL, Rioux JD, Hafler DA, Ascherio A. Integrating risk factors: HLA-DRB1*1501 and Epstein-Barr virus in multiple sclerosis. Neurology 2008;70:1113-1118.

5. Hedström AK, Lima Bomfim I, Barcellos L, et al. Interaction between adolescent obesity and HLA risk genes in the etiology of multiple sclerosis. Neurology 2014;82: 865-872.

6. de Heredia FP, Gómez-Martínez S, Marcos A. Obesity, inflammation and the immune system. Proc Nutr Soc 2012;71:332-338.

7. Grant RW, Dixit VD. Adipose tissue as an immunological organ. Obesity (Silver Spring) 2015;23:512-518.

8. Olsson T, Barcellos LF, Alfredsson L. Interactions between genetic, lifestyle and environmental risk factors for multiple sclerosis. Nat Rev Neurol 2017;13:25-36.

9. Ascherio A, Munger KL, Lünemann JD. The initiation and prevention of multiple sclerosis. Nat Rev Neurol 2012;8:602-612. 


\title{
Neurology \\ Neuroimmunology \& Neuroinflammation
}

\author{
Obesity's role in MS: An intervention target with possible interactions \\ Kathryn C. Fitzgerald and Ellen M. Mowry \\ Neurol Neuroimmunol Neuroinflamm 2021;8; \\ DOI 10.1212/NXI.0000000000000932
}

This information is current as of December 15, 2020

\section{Updated Information \& Services \\ References \\ Subspecialty Collections}

Permissions \& Licensing

Reprints including high resolution figures, can be found at:

http://nn.neurology.org/content/8/1/e932.full.html

This article cites 9 articles, 0 of which you can access for free at: http://nn.neurology.org/content/8/1/e932.full.html\#\#ref-list-1

This article, along with others on similar topics, appears in the following collection(s):

All epidemiology

http://nn.neurology.org//cgi/collection/all_epidemiology

Multiple sclerosis

http://nn.neurology.org//cgi/collection/multiple_sclerosis

Risk factors in epidemiology

http://nn.neurology.org//cgi/collection/risk_factors_in_epidemiology

Information about reproducing this article in parts (figures,tables) or in its entirety can be found online at:

http://nn.neurology.org/misc/about.xhtml\#permissions

Information about ordering reprints can be found online:

http://nn.neurology.org/misc/addir.xhtml\#reprintsus

Neurol Neuroimmunol Neuroinflamm is an official journal of the American Academy of Neurology.

Published since April 2014, it is an open-access, online-only, continuous publication journal. Copyright

Copyright $\odot 2020$ The Author(s). Published by Wolters Kluwer Health, Inc. on behalf of the American

Academy of Neurology.. All rights reserved. Online ISSN: 2332-7812.

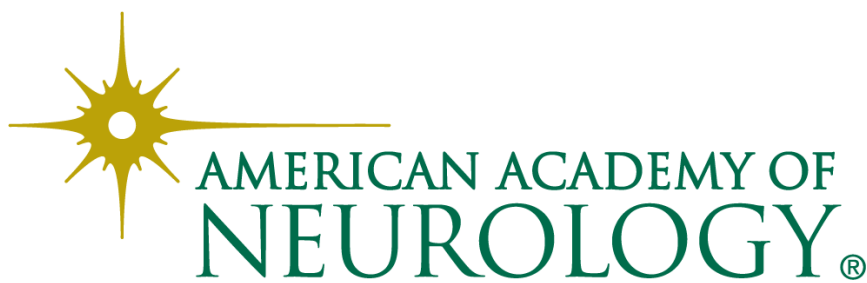

